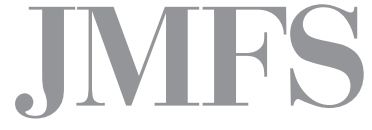

Journal of Management and Financial Sciences
Volume XIII

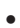

Issue 40 (March 2020)

pp. 57-72

SGH Warsaw School of Economics Collegium of Management and Finance

Kateryna Vaskivska

Department of Formation Space

Faculty of Mathematics, Computer Science

and Landscape Architecture

The John Paul II Catholic University of Lublin

Department of Economics and Management Faculty of Finance and Business Management Ivan Franko National University of Lviv

ORCID: 0000-0002-1615-3488

\title{
The development of the regional innovation system in Ukraine under decentralization
}

\section{ABSTRACT}

The main concepts of the term 'region' have been determined in this paper and the term 'innovation' has been analyzed. The problem of regional innovation system's place and role in the development of a region and its internal potential in its competitiveness has been emphasized. Moreover, the diagnostics model of innovation product implementation has been proposed as well as the comparison of innovation indexes, which are identified at the level of an individual country or a group of them. Finally, the Polish experience of the regional innovation system development under decentralization changes in the country has been explored.

Keywords: region, innovation, regional innovation system, innovation index, subject of the regional innovation system

JEL Classification Codes: J59, L19, O32, P11 


\section{Introduction}

In order to create an effectively functional innovation system, there should be primarily a deliberate and consistent state innovation policy implemented as well as the transition from the declaratory formation and the development of an innovation system to legislative implementation and practical realization of real tools of state-supported innovative activity. Innovation systems functioning within a regional structure over the last years has been a very widespread tool in the formation of economic policy both at the local and the regional level.

It is determined particularly by the fact that the current development trends point to the necessity of making innovation decisions and economic potential forming from the lowest level of the local self-government. Regional innovation systems are considered to be an answer to the global changes in 'the rules of a game' course.

That is why the local self-government authorities must use the new forming methods of their own concept development and improve the competitiveness of a given region. Innovation systems provide facilities, on the basis of the economic entity union, research institutes and local self-government authorities, to form priorities of the region's development at the general level. The objective of the study is to generalize theoretical experience and identify trends in the formation of regional innovation systems and in addition, regional innovation systems complementing the European Union policy (http://context.reverso.net/перевод/ английский-русский/enhance+competitivenessthe) concerning enhancement of regional competitiveness of regions, which is underlined by the topicality of the research, though its basic concepts have been explored in scientific literature.

\section{The theoretical aspects of the research into the categories of 'region', 'economic region' and 'innovation'}

There is no single meaning of the 'region' category at present. This is due to the availability of many concepts and factors which influence the formation and development of the region as an economic category. According to the Academic Explanatory Dictionary of the Ukrainian language, a region is defined as a certain territorial unit (area, zone, part of the country), which is distinguished from the other similar units by specific features (geographic, geological, ethnographic, economic, etc.) [Dictionary of the Ukrainian language, 1977, p. 477].

This definition of the region contains very few specifics and is non-informative, indeed the definition of the concept should be characterized by a list of features of the territory that could be determined as a region, which will allow for providing an effective separation of territories and their division, pointing to these dominants which distinguish the region as a scientific category. 
There is a similar problem with the definition of 'region' at the level of the European Commission and Eurostat, as the attention is focused on the position of distinct identification of its area, but without corporate affairs formed at this level.

It should be noted that this category could be considered from the point of view of international and regional economics. If the region research is based at the level of international economics, this category could be characterized as a group of countries which have a common geographical location, similar environmental conditions and other common aspects, then at the level of regional economics a region is defined as a complex of administrative territorial units of a country with a common geographical location, environmental conditions and economic specialization, etc. Therefore, the difference in the definition of this category exists only at the level of administrative-territorial division.

Ukrainian scientist V.I. Chuzhikov has substantively determined this category as an open hierarchical polystructural system basing on the territorial unity, which has similar sectoral, demographic and social structures, a formed common infrastructure, appropriate institutional and managerial multi-level taxonomic model [Chuzhikov, 2008, pp. 37-49].

An extended definition of the region is presented by Polish researcher K. Sekomski, who distinguishes main directions of the research [Secomski, 1982, pp. 26-28]:

- regions from the point of view of physical-spatial and geographic characteristics research - it refers to the natural features of the development of a territory, that is the natural environment, climatic features and the biosphere in general;

- regions from a position of the economic aspects distinguishing their development - they include features of the economic activity on the territory of a region, the level of production facilities development, available resource base, in particular the quality of labour force;

- regions as administrative and territorial units are characterized in the context of administrative division, which exists in a country and according to which territories are developing. A comprehensive approach to the definition of the 'region' category was made by S. Korenik, who within the above positions distinguishes a number of dominant factors in the region [Korenik, 1999, pp. 10-15]. He proposes distinguishing the types of regions on the basis of their unique features. Such factors, within distinguishing physical and geographical characteristics of a region, are biological, hydrological, geological and atmospheric. Economic regions include, considering the features of the production process, production and economic specialization, distribution system, peculiarities of management, infrastructure and network structure. Administrative ones - the peculiarities of the administrative and territorial structure, political, social and economic aspects of regional development. Accordingly, the typology of regions is proposed to be determined in the geographical, natural, climatic, anthropological, industrial, economic and administrative contexts.

In the context of our research, attention is given particularly to the economic region. Taking into account the sequence in the definition of the 'region' category and the focus on the necessity of the most effective division of the territory according to definite features, there could be distinguished such basic characteristics of an economic region as: 
- complete spatial resolution;

- available and formed system of economic relations;

- multifunctional formation;

- low level of border stability and high permeability;

- dynamism of development.

S. Korenik focuses on distinguishing features of an economic region, too; he identifies the following [Korenik, 1999, pp. 10-15]:

- the region unites similar basic units;

- it includes the system of external and internal interrelations, in this the internal component plays a key role in the development of the region;

- the region is characterized by a concrete direction of specialization;

- it is characterized by availability of labour force;

- the region to some extent is considered to be a closed system;

- it provides the existence of at least one big urban centre, around which the unification of all components of the region is provided.

Accordingly, the specificity of an economic region is defined by the level and the peculiarities of local economic development, which directly influences the level of the region competitiveness. In this context, it is worth drawing attention to the division of the regions according to their level of economic development, proposed by G. Gorzelak [Gorzelak, 1989, p. 34]:

- common features - characterized by a high level of economic development, that is an above average economic growth in a country and a positive trade balance;

- economic regions with a negative trade balance;

- weak regions develop more slowly than the state's economy in general, but having a positive trade balance;

- weak regions develop more slowly above the average in the country and have a negative trade balance.

Such systematization of economic regions makes it possible to analyse their competitiveness, identify the main factors of influence in terms of economic development, focus on the intensity and effectiveness of the implementation of innovative projects and the creation of an innovative system in economic regions.

This is a particularly topical matter, since in recent years the issue of the introduction of innovative models and tools in various spheres of regional economic development has become a priority in ensuring an adequate level of its competitiveness. This situation is primarily related to the process of globalization, as well as access to information, new knowledge in various fields and new technological solutions. Today the question of obtaining new information and knowledge at the regional level could be solved in different ways - both due to their acquisition in external markets from international corporations and foreign entities, as well as through self-education and the formation of research and development areas. 
As the issue of innovation development and its involvement at the regional level and in a region's development is particularly topical, an analysis of the definition of the 'innovation' category of leading economists is advisable at different periods (Table 1).

Analyzing the definitions and the methods of considering innovation in scientific categories presented in Table 1, common features in the definitions of different economists could be noted. Foremost, innovation is discussed as a new, non-use phenomenon of creativity. Nonetheless, innovation is not identified with the production of new goods and services, since it includes the usage of new approaches, for example, in governance, or some new creative knowledge.

Table 1. The peculiarities of the definition of the 'innovation' category in the scientific literature

\begin{tabular}{|l|l|}
\hline \multicolumn{1}{|c|}{ Author } & \multicolumn{1}{c|}{ Definition of the category } \\
\hline J. Friedmann & $\begin{array}{l}\text { Innovation is a result of the creative act providing for } \\
\text { rearrangement of existing and known elements in new structural systems [Friedmann, 1974, pp. 18-33] }\end{array}$ \\
\hline J. Loboda & $\begin{array}{l}\text { Innovation is a specific arrangement of ideas, procedures, or products of the material culture of a particular } \\
\text { local community. In this case, every local system should be considered as a spatial-temporal system within } \\
\text { which innovations, leading to quantitative and qualitative changes, are implemented [Loboda, 1983, pp. 15-28] }\end{array}$ \\
\hline M. Weresa & $\begin{array}{l}\text { Innovation are qualitative changes, both creative and imitative in technology, in labour and production } \\
\text { organization, management and marketing, which are characterized by novelty and originality and implemented } \\
\text { in an enterprise, market, region or within the international markets [Weresa, 2003, pp. 96-114] }\end{array}$ \\
\hline
\end{tabular}

Source: own study.

The development of the modern world is increasingly dependent on the development of regional information systems, which primarily affect the investment policy of a region and usage of its resource potential. Priority tasks of regional information systems are:

- continuous updating of a regional database: socio-economic characteristics and indicators of a region, its governance structure, partners, enterprises, science, education, social industry and other industries of the region's life;

- the coherence of information space of the region and its relationship with the state information system;

- veracity and quality of the information system;

- providing information security of state authorities, municipalities, businesses and civilians (population);

- to be the basis of the information economy and information society, to have and develop a database (knowledge) for it;

- to provide free, fast and high-quality access to the global network and availability of its information for consumers of the region.

Today regional information systems consist of the following components: subsystem of region administration; subsystem of city administration; educational information system; subsystem of enterprises' economic condition monitoring; regional referral system (hotels, restaurants, transport, theaters, stadiums, shopping and entertainment centers, etc.)

Regional and state informatization administrations have the purpose to create a reliable and simple competitive environment based on a mutually advantageous partnership of the public 
and private sector, including the population, which will provide a solution to the following tasks of the establishment, performance and development of regional information systems:

- integration of regional and national information systems;

- creation of a modern educational system which meets the requirements of an innovative and informative economy;

- identification of priority areas of innovation development of the region and the country as a whole;

- creation of the information economy based on the development of information technology and innovation;

- choice of competitive innovative products, competent to increase the innovative and informative potential of the region;

- establishment of an innovation funding system (state, municipal and private), choice of the most competitive innovation and innovative enterprises capable of creating clusters and developing cities, regions, sectors and spheres of the economy;

- development and provision of an innovation economy with an appropriate information structure.

Regional information systems contribute to the development of the business environment in a region, creating a favourable investment climate which has an effect on the well-being of the population and the socio-economic indicators of local self-government authorities within the region.

The systematic approach to innovation is characterized by the concept of regional innovation systems. The basis of this approach is the relations between entities in the process of development and use of innovative technologies. The system approach is based on the features of innovational activities which provide interconnections between enterprises, industries and regions for the purpose of the effective functioning of business.

The research of scientist B.A. Lundwall is devoted to the study of the phenomenon of national innovation systems [Lundwall, 2003, pp. 173-185]. At the end of the second half of the twentieth century, the problem of the functioning of national innovation systems was the subject of research by K. Freeman, who interpreted the national innovation system as "a network of interconnected institutions in the public and private sectors, whose activities and interaction initiate, modify and disseminate (...) innovations" [Freeman, 1987, p. 7]. At the same time, in his studies, R. Nelson considers national innovation systems as "a set of institutions whose interaction determines innovative productivity" [Nelson, 1993, pp. 3-22]. The concept of a regional innovation system emphasizes the characteristic features of an innovation system. According to P. Cook, the structure of regional innovation systems consists of centers for generating innovative ideas and subsystems for their use [Cook, 1992, pp. 365-382].

New trends that meet the requirements of the market and time are developing in the economic environment. They highlight the need for a systematic approach to innovation policy. The basis in the management of business processes is the use of unlimited opportunities associated with a spectrum of new knowledge, communication technologies, international 
mobility, and the activation of outsourcing. Horizontal management and the cluster approach in organizing economic activity should be highlighted among the main regularities of regional innovation systems formation (Finland's clusters can be an example) [Nekrasowa, 2014, pp. 133-134]. These approaches of managing the economy allow for providing the competitiveness of enterprises.

\section{The diagnostics of innovation product implementation}

Characterizing innovation, attention should be paid to its features, including the following:

- innovations are interdisciplinary and interactive; since they appear in a particular place with the participation of different subjects (private business entities, regional authorities, research centres, academic and scientific institutions, etc);

- implementation of innovation requires free and full exchange of information and knowledge among process participants;

- creation of innovative product expects a combination of different types of knowledge - from theoretical to technological;

- the implementation of an innovative product is an expensive and highly risky process and is characterized by the complexity of ensuring control over its conduct.

In general, innovation is focused on generating new knowledge and is primarily perceived as such new knowledge. At the same time, analyzing innovation, it is expedient to consider the possibilities of its implementation and determine the diagnostics indicators of this process (Figure 1).

The diagnostics of innovation product implementation is used both at the state and the international level. The most popular indicator, which is used for assessment of the innovation level within a country (and could be used for a level of a region), is the Summary Innovation Index, which was developed by the European Commission, PRO INNO EUROPE. This index includes 25 indicators, the analysis of which makes it possible to refer the research object to eight innovative measurements. The peculiarity of the analysis is the focus on three areas of analysis. The first one involves studying aspects which directly determine the conditions of innovative product creation, namely: human resources, system balance and the level of financial assistance. The second one is the activity of subjects in the innovation implementation, which consists of investment in innovation, communication and entrepreneurship. The third one is connected with the results of implementation, intellectual assets of innovation product development and includes the definitions of the next indicators: indicators of knowledge creation, indicators of innovation diffusion, indicators of innovation implementation, indicators of intellectual assets.

In addition to the Summary Innovation Index, the other innovation indicators of countries and regions are widely used. The most common ones are presented in Table 2. 
Figure 1. The diagnostic schematic model of innovation product implementation

- Financial resources

- Human resources

- Measures of innovative product protection (patent, intelectual property)
- The scale of the process

- Implementation speed of innovative decisions

- Growth potential after innovation
- The number of new realized products

- Percentage of new clients

- Returns on innovation investment.

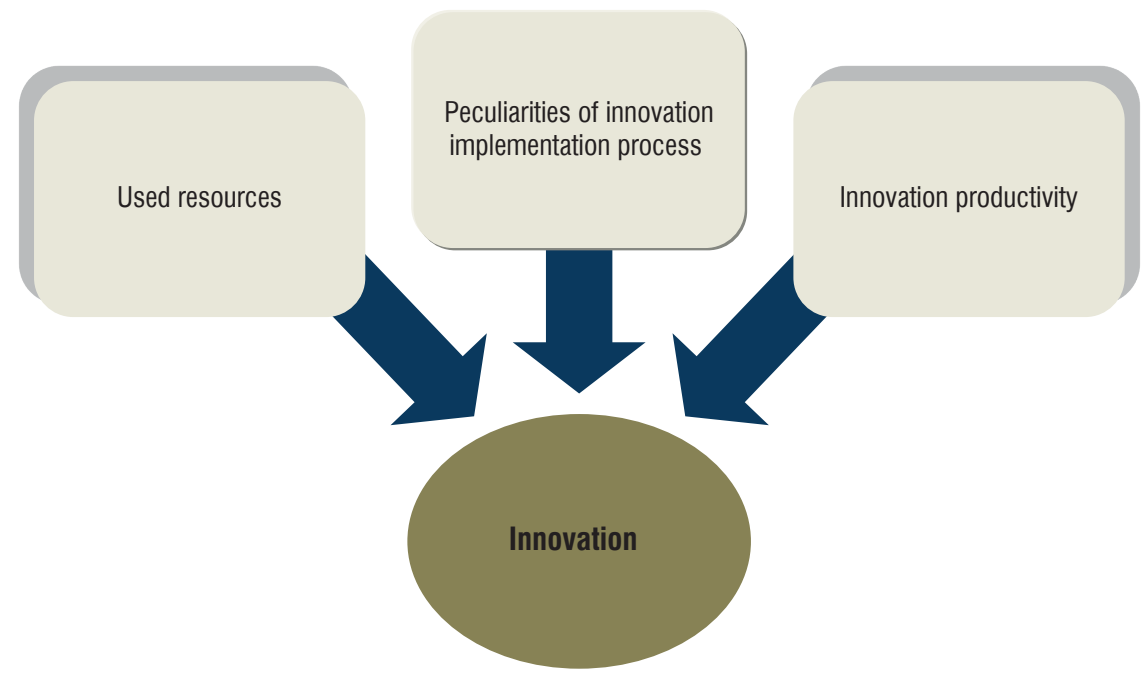

Source: own study.

According to the data presented in Table 2, there could be the following conclusions drawn regarding the differences and peculiarities of the calculation and use of the indicated indexes:

- the BCG Global Innovation Index is characterized by the study of innovation development conditions in a respective territory and determination of the innovation effectiveness and its definition implies taking into account the numerical indicators of the state development level that affect the dissemination of innovation, indicators of the innovation activity effectiveness and the economic implications of their implementation in various spheres;

- the INSEAD Global Innovation Index aims to identify the role of countries' innovation policy in ensuring their competitiveness at the international level; at the same time, attention is focused on interconnections and impact of the state on the direction of development of innovations and improvement of people's well-being; for determining the index, a significant number of different sources, information content and area of indicators are used;

- the Innovation Capacity Index is, on the contrary, sought to define the capacity of national economies to implement innovative products and to develop them, but the effectiveness of the innovation development characterized by this index is quite limited;

- the Summary Innovation Index is aimed at determining the impact of the external environment, the internal economic situation, and state policy on the process of all stages of the development and implementation of an innovative product.

The most innovative countries were Switzerland, the Netherlands and Sweden according to the data of the global innovation index for 2018 [The Global Innovation Index, 2018, p. 22]. 


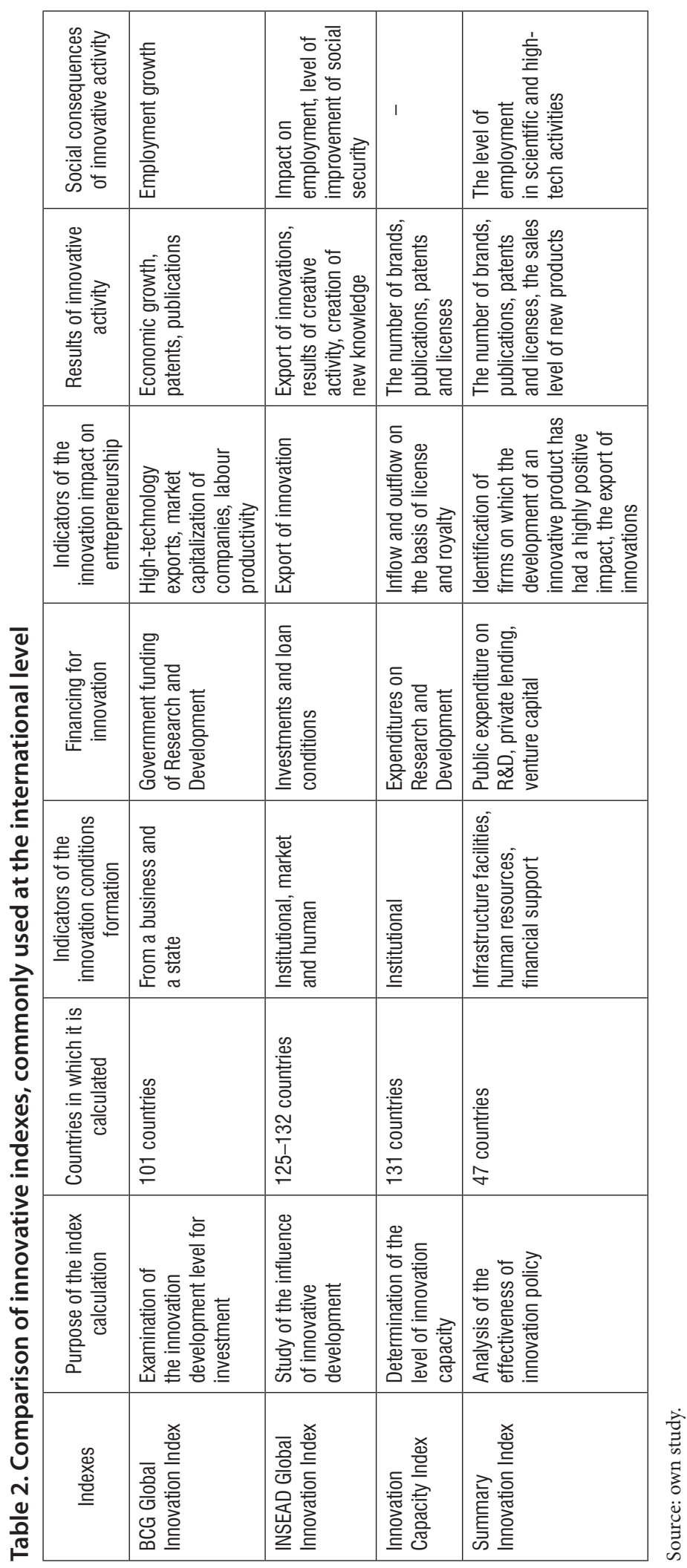


Focusing on the existence and the usage of indexes at both the international and individual state levels, determining the level of economy innovation and the capacity to implement innovative products, we would like to draw attention to the importance of the development of the innovative component in a region's economy.

Taking into account decentralization processes and sectoral reforms in public administration in Ukraine, the problem of a certain underestimation of the innovative development of the region and state economy should be emphasized.

Thus, in the Innovation Union Scoreboard rating, on the basis of which the Summary Innovation Index is determined, Ukraine has an index of 0.206 , which is twice as low as the average in the EU countries (0.544) and has the status of a 'forming innovator'.

This is primarily a consequence of the lack of implementation as a strategy for the innovative development of the economy at the state and regional levels, as well as the lack of necessary attention to this issue at the level of state bodies in general during the development of Ukraine as a state.

\section{Structural components of the regional innovation system}

Nowadays, the problem of innovation development of the economy receives much more attention at the central level, in particular, the National Council of Science and Technology Development has been established.

At the same time, this is only the beginning of work in this direction. Meanwhile, at the regional level, resuming the work on innovation development is not observed, although a clear definition of the innovation development policy at the level of the region is an especially urgent task in the context of decentralization processes. It is expedient to study the experience of the regions of Poland within the solution to this problem. In the 1990s, after the start of decentralization, the authorities of this country formed the concept of a regional innovation system, which determined the details of innovation policy in the regions. The decision to consolidate innovation development at the regional level arose because of the complexity of task implementation at the state level in general.

The development of a regional innovation system can help to solve problems that appear due to the large scope of innovative products implementation or their design. Such a system at the regional level can be developed according to the specialization of the region, which should be adapted to its specific features, and focus on those areas that require the attraction of less capital. It is important to note that such a system in the Polish regions operates on the basis of cooperation between subjects in the local area, which play a significant role in the development of the region, namely local self-government authorities of different levels, business structures and research centers (Figure 2). 
As you can see in Figure 2, the regional innovation system consists of:

- a subsystem of production and the provision of services (the role of its subject is the commercialization of innovative solutions produced by the system);

- an education and research subsystem (the task of its subjects is the generation of knowledge and its transformation into other subsystems);

- an institutional subsystem (includes institutions that provide support for the development of innovative products);

- a socio-cultural subsystem (defines the peculiarities of system development).

Let us construct a logical structural model of the construction business (cluster) (Figure 3).

The structural components of a construction cluster are:

- core of the cluster: construction organizations; enterprises producing building materials; interior and landscape design firms;

- cluster infrastructure: innovative infrastructure; the latest construction technologies; innovation infrastructure; the newest technologies of landscape design; the latest technologies of interior design; innovative products and materials;

- cluster service industry: services of design and budget institutions; services of research institutions; educational services; transport services; water supply, electricity, gas services; brokerage services; consulting services.

Figure 2. The structure of a regional innovation system

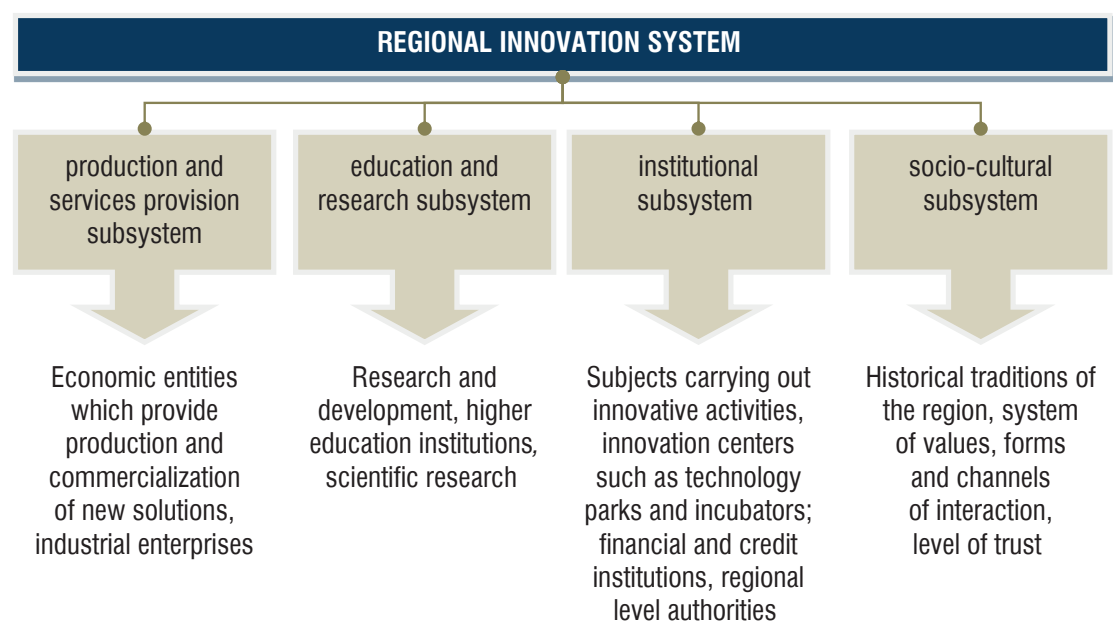

Source: own study.

The current trend is to promote clusters activity at regional, national and external economic levels, to develop effective methodological, informational, consulting and educational support for the implementation of cluster policy at sectoral and regional levels.

It is worth noting that the creation of industrial parks in small towns, including the territories of the old industrial zones is important, too. Therefore, among the directions of financial support improvement of region investment activity there could be distinguished: the 
growth of capital and foreign direct investment in the economic industry; the formation of a favorable regulatory environment in the region; development of entrepreneurship support infrastructure; further promotion of the business functioning cluster model in the region; intensification of existing and creation of new industrial parks. It will have a direct positive influence on the improvement of the investment climate in the region, the creation of new enterprises and new workplaces with the participation of investors.

Figure 3. A logical structural model of a construction cluster

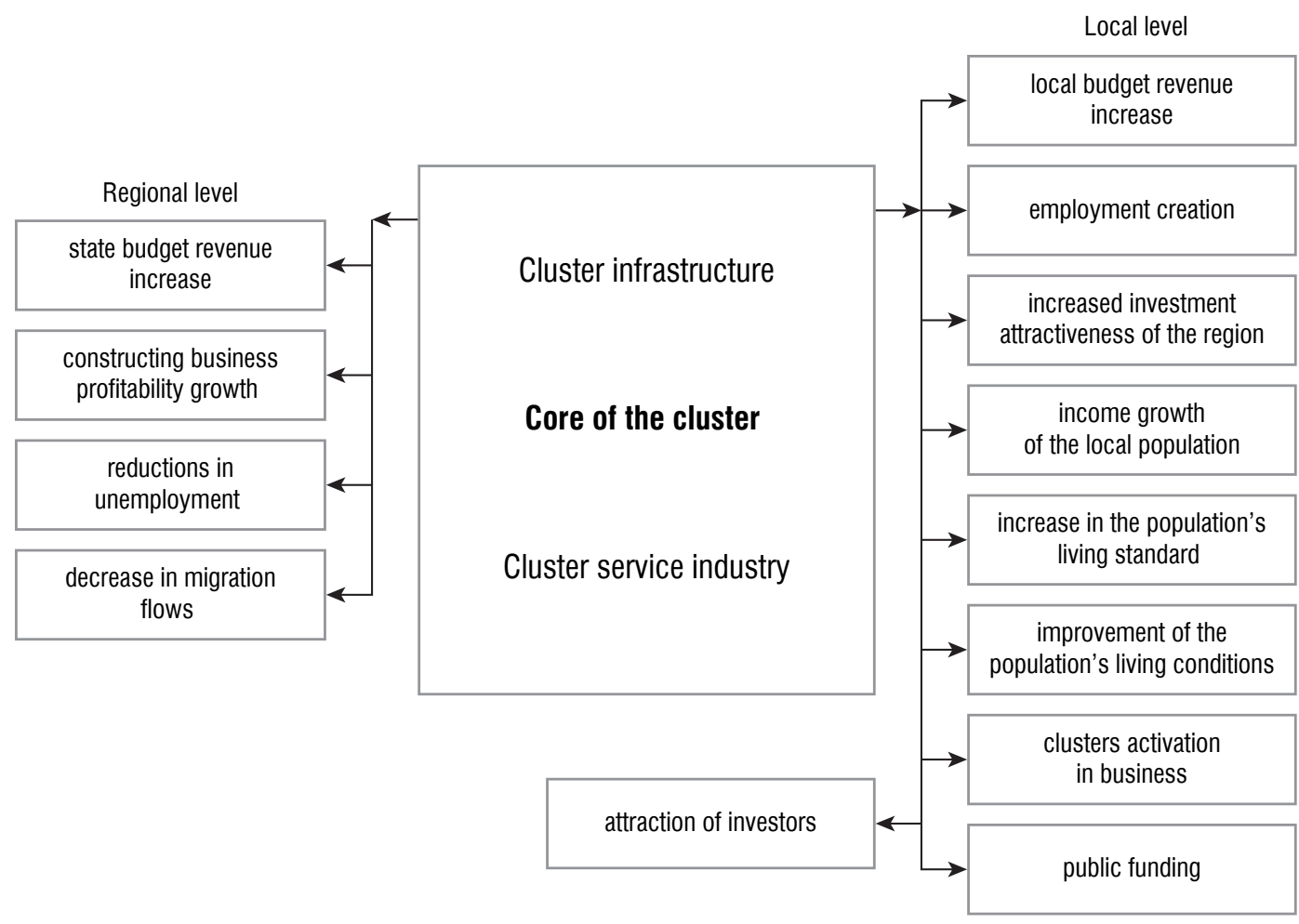

Source: own study.

In the conditions of deepening world economic relations, as well as the expansion of cooperation between different subjects of economic activity, competition in the world market, which involves the generation of new competitive advantages basing on the intensification of innovation processes, is increasing. Such a condition entails reviewing the existing mechanism of innovations in the state regulations, the formation of a qualitatively new policy for the development of specific regions, funding relevant processes, finding new opportunities in the market environment through which it would be possible to concentrate innovative resources in the regions concerned, solving existing socio-economic problems in future. The issue of regional development is extremely important for Ukraine, because, due to the unstable economic situation, the existing social imbalances in the development and activity 
of different social strata, as well as the military-political conflict in the east of the state, there is a problem in the development of a new, economically sound regional innovation system.

In this context, it will be appropriate to consider the issue of the region's economic potential, including its structural components, namely the investment potential, since it is through stimulation and development of investments that the state is able to strengthen the economy, create new workplaces, generate new productive capacities, stimulate the development of small and medium-sized businesses.

One should point out that the regional innovation system is characterized by openness, since it can generate external traffic if foreign organizations and institutions want to participate in its development (Figure 4). Thus, interconnections in the regional innovation system are characterized by duality: first, the presence of local level flows between individual entities of the system, and secondly, the presence of flows that go beyond the system, in particular, entities of the system with transnational corporations.

At the same time, interconnections between individual regions, that is between individual regional innovation systems, are possible if they see common goals in terms of sectoral or technological relations. This kind of cooperation between individual regions is advantageous especially in the absence of the necessary amount of capital in particular regions to achieve certain goals, or in the case of economies of scale.

The implementation of a regional innovation system should be based on a specific model of regional development, formed around smart specialization, in other words, the direction of activity and development of those areas of research and innovation work that provide the strengthening of the region's endogenous capacity.

Figure 4. Systemic interconnections in a regional innovation system
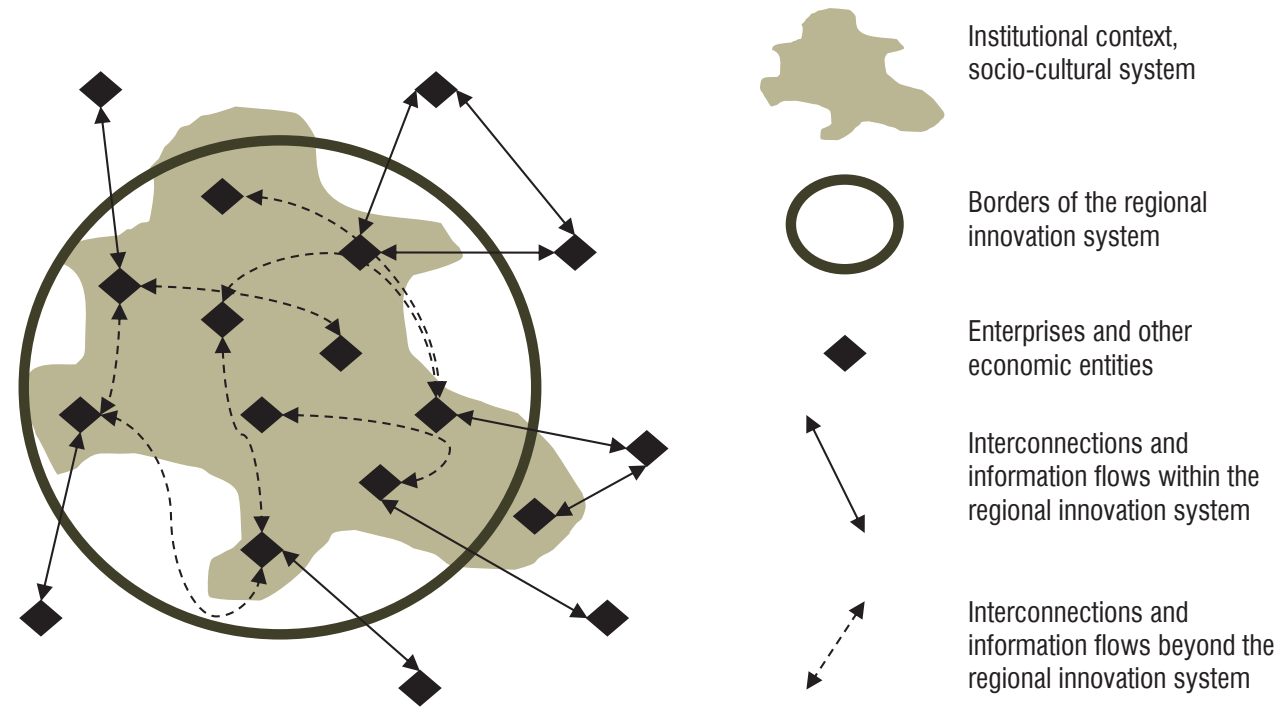

Source: own study. 
In Polish regions, the identification of such areas of smart specialization is primarily based on the definition of the main spheres of development at the level of the European Commission. As a result, for example, Lublin Voivodship was selected to implement four such areas of intellectual specialization: bioeconomics; healthcare; IT technologies; green energy [Regionalna strategia innowacji wojewodztwa Lubelskiego, 2014, pp. 39-45].

In general, the problem of the Polish regions in the field of innovation policy is a significant differentiation of the region development level and innovation activities. That is why at the state level and at the level of regional authorities, the main directions of action in terms of effective management in the implementation of the regional innovation system are determined [Regionalne Systemy Innowacji w Polsce. Raport z badan, 2013, pp. 97-121]. For the various subjects, the following tasks are identified:

- for state authorities:

- formation of the Innovative Regions Platform, the main goal of which is the development of a regional system of innovation and ensuring interconnections between subjects of innovation activity;

- providing funding for the implementation of innovative tasks which are common to all regions within the national innovation support programme. Such tasks should be carried out jointly at the expense of local government bodies, economic entities and other social partners to accelerate the process of creating a regional innovation system (in particular, in regions with a low level of innovation implementation capacity);

- development and implementation of decisions concerning effective and rapid knowledge transfer to the stage of their practical implementation;

- supplementing the programmes of innovative development at the central level of identification of possible auxiliary forms of innovation support - investing, inducing research work, etc.;

- for local self-government authorities:

- creation and implementation of an action plan for the formation of innovative positions in the region, in particular on the basis of identifying the strengths and weaknesses of the economy;

- formation of a regional innovation strategy as an operational programme for conducting the regional development strategy to increase the level of innovation influence on the economic growth of the regions;

- provision in the management process of the regional innovation system of the leading role of regional authorities in accordance with the principles of partnership and participation of interested parties of the regional innovation system;

- definition of the exchange mechanism of views, ideas in the process of cooperation and transfer of knowledge between subjects of the regional innovation system within the separate regions as well as in the interregional system for accelerating the training of participants in regional innovation systems; 
- identifying measures to improve the efficiency of the existing institutes of the innovative business environment (scientific and technical parks, clusters, technology transfer centers, etc.) and the growth of the influence of innovation institutes on the level of innovations in the region;

- elaboration of an action strategy for the development of innovative sectors and ensuring the use of the intellectual specialization concept as a part of regional strategies;

- the foresight of the simultaneous support of specific projects using various additional forms of support, including support of investment, research institutes and human capital;

- For other subjects of the regional innovation system:

- improving of the innovativeness of enterprises and institutions employees;

- increasing of the level of active participation in the regional system management of the innovation system to enhance the effectiveness of the management process and increase the benefits of the participation of all interested parties.

\section{Summary}

The studied experience demonstrates that the implementation of a systemic and cluster economic policy aimed at increasing the competitiveness of enterprises will contribute to the formation and effective functioning of regional innovation systems. Practice requires a new approach to the generation of innovations, namely in the conditions of decentralization. This characterizes the self-organized paradigm of interaction of innovations, knowledge, communications, technical skills and means that influence the efficiency of regional innovation systems.

The creation of an innovation system in a region has a significant impact on the formation of competitive advantage and determines the priority goals of economic development. Analyzing the experience of the Polish regions, which became more active in this direction in the early 90s, there could be seen an already formed scheme of an effective policy concerning regional innovation system development at the level of regional authorities. Therefore, special attention should be paid to these issues in Ukraine. In particular, clusters serve as structural elements of regional innovation systems. Large enterprises and their associations can act as system integrators for regional innovation ecosystems and such kind of activity serves as the basis for their efficient development.

However, taking into account the limited resources and leverage for the business environment, a systemic and consistent state policy of clusters development support can contribute to a significant fostering of economic development and an effective functioning of a regional innovation system due to the creation of favorable business conditions and the adequate resourcing of their targeted initiatives and projects. 


\section{References}

1. Chuzhikov, V.I. (2008). Global regionalism: history and modern methodology: Monograph. K.: KNEU, p. 272.

2. Cooke, P. (1992). Regional innovation systems: competitive regulation in the new Europe. Geoforum, No. 23, pp. 365-382.

3. Dictionary of the Ukrainian language: in 11 volumes. (1997). Volume 8, p. 477. Retrieved form: http://sum.in.ua/s/reghion (accessed: 17.04.2019).

4. Freeman, C. (Ed.) (1987). Technology policy and economic performance: Lessons from Japan. London: Pinter. Retrieved from: https://academic.oup.com/cje/article-abstract/19/1/5/1708372 (accessed: 07.04.2019).

5. Friedmann, J. (1974). Ogólna teoria rozwoju spolaryzowanego. Przegląd Zagranicznej Literatury Geograficznej. 1-2, Warszawa: PAN, pp. 18-33.

6. Gorzelak, G. (1989). Economic reform in Poland under conditions of regional development. The Economist, No. 4, 1989, p. 34.

7. Korenik, S. (1999). Development of an economic region on the example of Lower Silesia. Research Papers of Wrocław University of Economics, No. 131. Wroclaw: Wroclaw University of Economics, pp. 10-15.

8. Loboda, J. (1983). Development of the concepts and models of spatial diffusion of innovations. Wrocław - 1987. Flow of information and spreading of innovations in the local communities of agricultural region on the example of Lower Selesia. Works of IG UW B, No. 6, Wroclaw, pp. 15-28.

9. Lundvall, B.-A. (2003). Why the New Economy is a Learning Economy, Economia e Politica Industriale: Rassegna trimestrale diretta da Sergio Vaccà. Milano: FrancoAngeli s.r.l., No. 117, pp. 173-185.

10. Nekrasova, L.A., Popenko, S.O. (2014). Cluster formation as an innovation direction economic development. Economy: the realities of time. Scientific Journal, No. 2(12), pp. 133-134. Retrieved from: http://economics.opu.ua/files/archive/2014/n2.html (accessed: 02.11.2019).

11. Nelson, R., Rosenberg, N. (1993). Technical innovation and national systems. [In:] R. Nelson (Ed.). National Innovation Systems: A Comparative Analysis. New York. Oxford: Oxford University Press, pp. 3-22.

12. Regionalna strategia innowacji wojewodztwa Lubelskiego do 2020 (2014). Lublin, pp. 39-45. Retrieved from: http://rsi.lubelskie.pl/images/794_RSI.pdf (accessed: 23.06.2019).

13. Regionalne Systemy Innowacji w Polsce. Raport z badań (2013), pp. 97-121. Retrieved form: https://www.parp.gov.pl/files/74/81/626/15705.pdf (accessed: 14.05.2019).

14. Secomski, K. (1982). Ekonomika regionalna. Warszawa: Wydawnictwo PWE, pp. 26-28.

15. The Global Innovation Index (2018). Energizing the World with Innovation. Retrieved form: https://www.wipo.int/edocs/pubdocs/en/wipo_pub_gii_pdf (accessed: 01.11.2019).

16. Weresa, M., Brdulak, H., Goleebiowski, T. (2003). Innovative potential of Polish eonomy; position in the world and the region. Common Europe - innovation in business operations. Warszawa: Difin, pp. 96-114. 